\title{
Mesophilic Mycobiota of Composted Sorghum Wastes in Egypt
}

\author{
Youssef, M.S. ${ }^{1}$, El-Maghraby ${ }^{1}$, O.M., Hassan,A.A. ${ }^{2}$, Rashwan, M.A.A ${ }^{2}$. \\ ${ }^{1}$ Botany and Microbiology Department, Faculty of Science, Sohag University, Egypt. \\ ${ }^{2}$ Agricultural Research Center, Giza, Egypt
}

Rec. 19 Oct, 2015 Accept. 25 Nov, 2015

\begin{abstract}
Seven composted heaps in addition to the control heap (without microbiological inoculation) were inoculated with six highly ligno-cellulolytic microorganisms singly or in mixed forms as accelerators of the decomposition process for 60 days until compost maturity at room temperature. Throughout composting process at different interval periods $(15,30,45 \& 60$ days), mycological survey was performed to select the most effective composts for research continuation. Nineteen fungal species belonging to 9 genera plus to one sterile mycelia were isolated from composted heaps on Czapek's-dextrose and potato-dextrose agar media using dilution-plate method accounting collectively $1696 \times 10^{4} \mathrm{cfu} / \mathrm{g}$.The total fungal count of all treatments ranged between $113-545 \times 10^{4} \mathrm{cfu} / \mathrm{g}$ and it increased with microbial inoculation. Aspergillus, Penicillium and Fusarium were the most prevalent genera in composting process.A. niger,A. fumigatus and $P$. chrysogenum were the most predominant species. Mucor racemosus, Fusarium solani, A. terreus, A. flavus,Emericella nidulans, A. foetidus, A. subsessils and $F$. incarnatum were isolated in moderate frequencies of occurrence. While, Trichoderma hamatum, $P$. brevicompactum, A. sydowii, A. ochraceous, and Saccharomyces cervisiae were isolated in low frequencies of occurrence.
\end{abstract}

Key words: cereal wastes, mesophilic fungi, compositing, sorghum waste, recycling.

\section{Introduction}

Cereal crops are mostly grasses cultivated for their edible seeds (actually a fruit called a caryopsis). Cereal grains are grown in greater quantities worldwide than any other type of crop and provide more food energy to the human race than any other crop (http://en.wikipedia.org/wiki/Grains). The seven principal cereals grown in the world are wheat, maize, rice, barley, oats, rye and sorghum. Nowadays, cereals provide a very significant proportion of both human and animal diets. Wheat and rice are the most important crops worldwide as they account for over $50 \%$ of the world's cereal production. In the UK, wheat is the cereal most commonly used for the manufacture of food products, although many other types of cereals (e.g. maize, sorghum and barley) are used. The starchy carbohydrates which are provided by cereals are essential in human nutrition. Rice is a stable diet for half the world's population, the remaining half cultivating the other cereals pending on climate and soil (Arvanitoyannis and Tserkezou, 2008).

Egypt is famous for a huge number of sorghum wastes, there are more than 336.2 thousands feddan per year cultivated by sorghum (FAO, 2013) distributed all over Egypt. Large quantity of sorghum wastes becomes a great problem leads to different environmental pollutions. Disposal of such quantities could solve potential pollution problems and result in the loss of relatively valuable resources, suitable for meeting a variety of national needs. Sorghum waste is considered a suitable raw material for recycling because it is produced in large quantities in relatively localized areas. Compost is considered as a suitable means for 
disposal and recycling such large quantities of wastes (El-Shafei et al., 2008).

Most Egyptian soils especially sandy calcareous soils in newly reclaimed areas are usually deficient in organic matter, nitrogen, available and micronutrients. Therefore, the chemical fertilizers have been intensively used as alternative source of organic fertilizers. The intensive use of chemical fertilizers has been found to increase the pollution of soil, water and food. Therefore using agricultural wastes as soil amendments on farmland instead of burning is an attractive alternative because it allows for some cost recovery, improves soil physical properties and recycles the carbon into the soil (Abdel-Motaal, 2004).

Crop biofertilization in the last few decades becomes appositive alternative to chemical fertilization. Biofertilizers are safe for human, animal and environment that reduce the great pollution occurs in our environment. Also, they are responsible for soil humus formation, improving nutrients growth, yield as well as physical and chemical properties of plants and their productions (Hammam, 2003, Ahmed et al., 2005, and El-Shenawi et al., 2008).

Organic fertilizers not only increases the organic matter in the soil but also enhances the available $\mathrm{P}, \mathrm{K}$ and most micronutrients through their effects on lowering soil $\mathrm{pH}$. Using these fertilizers improve water use effecting. Also, organic nitrogen fertilizers are responsible for avoiding all forms of pollution that may result from conventional agriculture techniques. In addition, the high cost of inorganic fertilizers is considered a big problem effacing fruit crops growers and to their roles on health problem and environmental pollution (Nijjar, 1985 and Miller et al., 1990, Yang et al., 2013).

Composting defined as the biological degradation of organic materials to a humuslike substance by natural microbiological processes constantly carried out in nature (Ancuta et al., 2011). Also, Mini et al. (1999) summarized the composting process as the biological decomposition of organic wastes under controlled conditions to a state which is sufficiently stable for utilization. Animal and human wastes, crop residues, as well as aquatic plants are considered the main resources available for composting. The crop residues, readily mineralizeable organic carbon, protein, cellulose, hemicellulose, lipids, and lignin could be the main resources for composting (Gaur, 1986, Gabhane et al., 2012).

\section{Materials and Methods \\ Collection of sorghum wastes samples:}

Sorghum plant wastes such as leaves, stems, roots, ears were collected from different sorghum farms in Sohag Governorate to study different physical and chemical properties, microflora (fungi and bacteria), possibility using as natural compost and enrichment it with other organic manures such as farmyard and chicken manure.

\section{Determination of moisture content:}

Twenty-five grams of freshly collected sorghum wastes, farmyard manure, chicken manure and mixture of them (original compost heap sample) were dried in oven at $\mathbf{1 0 5}^{\circ} \mathbf{C}$ for about 24 hours, and then reweighed. The percentage of moisture content was then calculated according to the following equation:

$\%$ moisture content $=\frac{A-B}{A} \times 100$

Where:

$\mathbf{A}=$ weigh before drying

$\mathbf{B}=$ weigh of dried sorghum wastes

Isolation of fungi from different treatments of composting process of sorghum wastes

\section{Dilution-plate method:-}

The dilution-plate method was used for isolation of fungi from different treatment periods of composting process of sorghum wastes as described by Johnson et al. (1959). Total counts of mesophilic fungi were determined by using potato-dextrose agar medium and Czapek's-dextrose agar medium supplemented byrose-bengal (15 ppm) (SubbaRoa, 1984).Ten plates were used for each sample and incubated at $28 \pm 2^{\circ} \mathrm{C}$ (five plates for each medium) for 7 days, during which the developing colonies were identified and counted (expressed as colony forming unit "cfu" per g dry sample). The average number of colonies per plate was multiplied by the dilution factor to obtain the number per gm. dry weight in the original samples. 
Identification of fungal genera and species:

The fungal isolates were tentatively identified microscopically on the basis of their critical morphological structure (Moubasher, 1993). Isolates that failed to produce reproductive structures after 3-4 weeks of incubation were referred to as sterile mycelia, and divided into morphospecies according to their culture characteristics.

The following references were used for the identification of fungal genera and species (purely morphologically, based on microscopical characters).Raper and Thom (1949), Raper and Fennell (1965), Booth (1971 \& 1977), Christensen and Raper (1978), Brycekendrick et al. (1980), Pitt (1985), Lawrence (1989), Klich and Pitt (1992), Moubasher (1993), Leslie and Summercell (2006),

\section{Preparation of compost}

\section{Inoculating microorganisms:}

Inoculating molds and yeast were isolated from sorghum wastes on potato-dextrose agar medium (PDA) at $28^{\circ} \mathrm{C}$, while Bacillus sp. was isolated from the same material on nutrient agar medium at $45^{\circ} \mathrm{C}$.

\section{Inoculum preparation:}

Moulds and yeast inocula were prepared by inoculation of spore suspensions $250 \mathrm{ml}$ of $A$. niger, Mucor racemosus, Tichoderma hamatum, sterile myceliaand Saccharomyces cervisia, separately, under aseptic condition. Inoculated Bacillus sp. was prepared by inoculation of sterilized $250 \mathrm{ml}$ nutrient broth for 48 hours at $45^{\circ} \mathrm{C}$ under aseptic conditions.

\section{Preparation of composted heaps:}

The experiment was carried out at the laboratory of physiology of fungi, Faculty of Science, Sohag University to investigate the possibility of using different ligno-cellulolytic microorganisms as a starter for composting of sorghum wastes (S.W) with farmyard and chicken manure to accelerate the process of decomposition and production of high quality compost rich with many essential elements, which was also targeted during this investigating.

Raw shredded sorghum wastes (S.W) were enriched with water (50-60\%) according to Turpeinen (2007) before formulating the heaps and arranged in composting beds, mixed with chicken manure $(\mathrm{CM})$ and farmyard manure (FYM) in ratio of $1: 1: 1$ and added the inoculums. Each compost heap was $30 \mathrm{~kg}$.

A combination between raw materials and microorganisms under the study were constructed in different separated eight treatments as the following:

TA: Sorghum broken wastes SBW (control-1).

TB: $\mathrm{SBW}+\mathrm{CM}+\mathrm{FYM}$ (control-2).

$\mathrm{TC}: \mathrm{SBW}+\mathrm{CM}+\mathrm{FYM}+$ Aspergillus niger + sterile mycelia + Trichoderma hamatum + Mucor racemosus + Bacillus sp.

TD: $\mathrm{SBW}+\mathrm{CM}+\mathrm{FYM}+$ Trichoderma hamatum + Bacillus sp.

TE: $\mathrm{SBW}+\mathrm{CM}+\mathrm{FYM}+$ Aspergillus niger + Bacillus sp.

TF: $\mathrm{SBW}+\mathrm{CM}+\mathrm{FYM}+$ sterile mycelia + Bacillus sp.

TG: $\mathrm{SBW}+\mathrm{CM}+\mathrm{FYM}+$ Mucor racemosus + Bacillus sp.

$\mathrm{TH}: \mathrm{SBW}+\mathrm{CM}+\mathrm{FYM}+$ Saccharomyces cervisiae + Bacillus $\mathrm{sp}$.

During composting, materials were manually mixed every week throughout the composting period for air circulation and temperature homogeneity. Three compost samples of each heap were taken every 15 days to determine the chemical properties. The moisture levels of the heaps were measured gravimetrically every week and appropriate amount of water was sprinkled onto the heap to increase the moisture content up to $60 \%$ (Turpeinen, 2007).

\section{Results and Discussion:}

Based on oven-dry method, the average moisture content percentage of sorghum wastes was $3.9-4.4 \%$. Whereas, the average moisture content percentages of farmyard manure and chicken manure were 10.9 - 11.6 and 5.2- 5.8, respectively. Also, the average moisture content percentage of mixture of them (original compost heap sample) was 18.2 -18.4 .

In this study, many strains of lignocellulose decomposing organisms such as Aspergillus niger, Trichoderma hamatum, Mucor racemosus, sterile mycelia, Bacillus sp. and Saccharomyces cervisiae were usedas inoculums into compost heaps as microbial enrichment to accelerate composting process for efficient recycling and breakdown of 
sorghum wastes and additive materials to obtain the best compst that can produce high yield with the best characters of wheat plant (Giza, 168) as plant test.

The following reports and results are in full agreement with this application. This applied method was effective in recycling of plant and organic wastes as reported by (Martin and Gershuny, 1992). that there are two ways in which may influence a compost heap: (1) by introducing strains of microorganisms that are effective in breaking down of organic matter and (2) by increasing the nitrogen and other nutrients content of heap. (Diaz et al. 1993). reported that the most active organisms in the composting process are bacteria, fungi and actinomycetes. In respect to microbial enrichment of compost, (Tengerdy and Szakacs, 2003). reported that enrichment of the process of ligno-cellulose composting with Aspergillus and Trichoderma strains greatly increased the availability of different nutrients as compared with control (non inoculated treatment).

In respect to microbial enrichment of compost, also, (Gaur, 1987; Omima AbdelMonsef, 2010 and Liu et al., 2011). reported that efficient cellulolytic fungi such as Aspergillus, Trichoderma and Penicillium accelerated composting for efficient recycling of crop wastes with high $\mathrm{C} / \mathrm{N}$ ratio and reduced the composting period by about one month. (Requena et al.,
1997). had found that the inoculation of turnip compost with ligno-cellulolytic microorganisms (Trichoderma viride or Bacillus sp.) increased the degree of humification of organic matter and improve its quality as soil amendments. (Tengerdy and Szakacs 2003). reported that enrichment of the process of ligno-cellulose composting with Aspergillus and Trichoderma strains greatly increased the availability of different nutrients as compared with control (non inoculated treatment).

(Kumar et al.,2008). indicated that to make the process of lignin degradation economically viable, inoculation with ligno-cellulolytic microorganisms may prove beneficial. Since no single organism produces all the enzymes necessary for bioconversion of ligno-cellulose to optimum level, there is need to use a consortium of ligno-cellulolytic microorganisms, which can act synergistically for rapid bioconversion of agriculture residues without any chemical pretreatment.

In the present study, 19 fungal species belonging to 9 genera plus to sterile mycelia were isolated from compost heaps composed of sorghum wastes and the additive materials during eight different treatments at $28^{\circ} \mathrm{C}$ on Czapek's and PDA media using dilution-plate method accounting collectively $1696 \times 10^{4}$ $\mathrm{cfu} / \mathrm{g}$. The total fungal count of all treatments ranged between $113 \times 10^{4}-545 \times 10^{4} \mathrm{cfu} / \mathrm{g}$ as shown in Table (1).

\begin{tabular}{|c|c|c|c|c|c|c|c|c|c|c|c|c|c|c|c|c|c|c|c|c|}
\hline \multirow{3}{*}{+} & \multicolumn{16}{|c|}{ Compost Treatments } & \multirow{3}{*}{$\begin{array}{c}\text { General } \\
\text { total } \\
\text { count }\end{array}$} & \multirow{3}{*}{$\%$} & \multirow{3}{*}{$\bar{Z}$} & \multirow{3}{*}{$\begin{array}{l}\mathbf{O} \\
\mathbf{R}\end{array}$} \\
\hline & \multicolumn{2}{|c|}{ TA } & \multicolumn{2}{|c|}{ TB } & \multicolumn{2}{|c|}{ TC } & \multicolumn{2}{|c|}{ TD } & \multicolumn{2}{|c|}{ TE } & \multicolumn{2}{|c|}{ TF } & \multicolumn{2}{|c|}{ TG } & \multicolumn{2}{|c|}{ TH } & & & & \\
\hline & $\underset{H}{U}$ & $\overline{\mathbf{Z}}$ & $\underset{H}{U}$ & $\overline{\mathbf{Z}}$ & $U_{H}$ & Z & $\underset{H}{U}$ & Z & $\underset{H}{U}$ & 己 & $\underset{H}{U}$ & 己 & U & $\overline{\mathbf{Z}}$ & $\underset{H}{U}$ & 己 & & & & \\
\hline Total count & 113 & & 118 & & 137 & & 234 & & 545 & & 258 & & 163 & & `128 & & 1696 & & & \\
\hline Aspergillus & 78 & 8 & 59 & 8 & 77 & 8 & 99 & 8 & 168 & 8 & 78 & 8 & 93 & 8 & 57 & 8 & 709 & 41.80 & 64 & $\mathrm{H}$ \\
\hline A. $\quad$ niger & 46 & 7 & 25 & 8 & 16 & 5 & 42 & 7 & 56 & 7 & 19 & 7 & 23 & 8 & 13 & 6 & 240 & 14.15 & 55 & $\mathrm{H}$ \\
\hline A. fumigatus & 8 & 3 & - & - & 11 & 6 & 22 & 7 & 52 & 6 & 25 & 5 & 37 & 8 & - & - & 155 & 9.14 & 36 & $\mathrm{H}$ \\
\hline A. $\quad$ terreus & 8 & 3 & 7 & 4 & 7 & 2 & - & - & - & - & - & - & 24 & 8 & - & - & 46 & 2.71 & 25 & $\mathrm{M}$ \\
\hline A. flavus & - & - & 11 & 4 & 43 & 7 & 14 & 6 & - & - & 21 & 7 & - & - & 27 & 8 & 116 & 6.84 & 24 & $\mathrm{M}$ \\
\hline A. foetidus & 16 & 4 & 16 & 5 & - & - & - & - & - & - & 13 & 5 & - & - & 17 & 7 & 62 & 3.66 & 21 & $\mathrm{M}$ \\
\hline A. $\quad$ subsessils & - & - & - & - & - & - & 13 & 5 & 13 & 3 & - & - & - & - & - & - & 26 & 1.53 & 16 & $\mathrm{M}$ \\
\hline A. $\quad$ sydowii & - & - & - & - & - & - & - & - & 38 & 6 & - & - & 9 & 5 & - & - & 47 & 2.77 & 11 & $\mathrm{~L}$ \\
\hline A. ochraceous & - & - & - & - & - & - & 8 & 4 & 9 & 4 & - & - & - & - & - & - & 17 & 1.00 & 8 & $\mathrm{~L}$ \\
\hline Penicillium & - & - & 15 & 6 & 15 & 5 & 19 & 5 & 186 & 8 & 20 & 8 & - & - & 27 & 8 & 282 & 16.63 & 40 & $\mathrm{H}$ \\
\hline P. chrysogenum & - & - & - & - & 15 & 5 & 19 & 5 & 133 & 8 & 20 & 8 & - & - & 12 & 7 & 199 & 11.73 & 33 & $\mathrm{H}$ \\
\hline
\end{tabular}

Table. 1. Comparison of total counts and number of cases of isolation of mesophilic mycoflora of compost heaps isolated during different treatments of composting process.using dilution-plate method at $28^{\circ} \mathrm{C}$. 
Total countof fungiincreased with microbial inoculation which accelerate decomposing wastes and additive materials tomicronutrientsthatencouraged and activated fungal growth.Total count of fungi and number of species recorded the maximumvaluesin treatment $\mathrm{D}\left(545 \times 10^{4}\right.$ cfu/g and 5 genera \& 10 species). While the lowest total counts were recorded in treatment A $\left(113 \times 10^{4} \mathrm{cfu} / \mathrm{g}\right)$, without any microbial inoculation, which considered as control, treatment B $\left(118 \times 10^{4} \mathrm{cfu} / \mathrm{g}\right)$ and treatment $\mathrm{H}$ $\left(128 \times 10^{4} \mathrm{cfu} / \mathrm{g}\right)$ as stated in Table (1), Figs 1 $(\mathrm{A} \& \mathrm{~B})$.

\begin{tabular}{|c|c|c|c|c|c|c|c|c|c|c|c|c|c|c|c|c|c|c|c|c|}
\hline \multirow{3}{*}{$\begin{array}{c}\text { Fungal genera and } \\
\text { species }\end{array}$} & \multicolumn{16}{|c|}{ Compost Treatments } & \multirow{3}{*}{$\begin{array}{c}\text { General } \\
\text { total } \\
\text { count }\end{array}$} & \multirow{3}{*}{$\%$} & \multirow{3}{*}{$\bar{Z}$} & \multirow{3}{*}{$\begin{array}{l}\mathbf{O} \\
\mathbf{R}\end{array}$} \\
\hline & \multicolumn{2}{|c|}{ TA } & \multicolumn{2}{|c|}{ TB } & \multicolumn{2}{|c|}{$\mathrm{TC}$} & \multicolumn{2}{|c|}{$\mathrm{TD}$} & \multicolumn{2}{|c|}{$\mathrm{TE}$} & \multicolumn{2}{|c|}{$\mathrm{TF}$} & \multicolumn{2}{|c|}{$\mathrm{TG}$} & \multicolumn{2}{|c|}{$\mathrm{TH}$} & & & & \\
\hline & U & $\bar{Z}$ & U & 己 & U & 己 & U & $\bar{Z}$ & U & 己 & U & 己 & U & $\bar{Z}$ & U & 乙 & & & & \\
\hline P. brevicompactum & - & - & 15 & 6 & - & - & - & - & 53 & 5 & - & - & - & - & - & - & 68 & 4.01 & 11 & $\mathrm{~L}$ \\
\hline P. restrictum & - & - & - & - & - & - & - & - & - & - & - & - & - & - & 15 & 7 & 15 & 0.89 & 7 & $\mathrm{R}$ \\
\hline Fusarium & 13 & 5 & - & - & 4 & 2 & 34 & 8 & - & - & 57 & 8 & 21 & 8 & 13 & 6 & 142 & 8.37 & 37 & $\mathrm{H}$ \\
\hline F. solani & 13 & 5 & - & - & - & - & 34 & 8 & - & - & 28 & 8 & 21 & 8 & - & - & 96 & 5.66 & 29 & $\mathrm{M}$ \\
\hline F. incarnatum & - & - & - & - & 4 & 2 & - & - & - & - & 29 & 8 & - & - & 13 & 6 & 46 & 2.71 & 16 & $\mathrm{M}$ \\
\hline Sterile mycelia & 3 & 2 & 13 & 6 & 13 & 6 & 13 & 6 & - & - & 102 & 7 & 11 & 6 & - & - & 155 & 9.14 & 33 & $\mathrm{H}$ \\
\hline Mucor racemosus & 5 & 3 & 19 & 8 & 5 & 2 & 13 & 4 & 122 & 8 & 1 & 1 & 25 & 6 & - & - & 190 & 11.20 & 32 & $\mathrm{M}$ \\
\hline $\begin{array}{l}\text { Emericella } \\
\text { nidulans }\end{array}$ & 14 & 5 & 12 & 6 & - & - & - & - & 37 & 6 & - & - & - & - & 14 & 6 & 77 & 4.54 & 23 & $\mathrm{M}$ \\
\hline $\begin{array}{c}\text { Trichoderma } \\
\text { hamatum }\end{array}$ & - & - & - & - & 23 & 7 & 56 & 8 & - & - & - & - & - & - & - & - & 79 & 4.66 & 15 & $\mathrm{~L}$ \\
\hline $\begin{array}{c}\text { Saccharomyces } \\
\text { cervisiae }\end{array}$ & - & - & - & - & - & - & - & - & - & - & - & - & - & - & 17 & 8 & 17 & 1.00 & 8 & $\mathrm{~L}$ \\
\hline $\begin{array}{l}\text { Rhizopus } \\
\text { stolonifer }\end{array}$ & - & - & - & - & - & - & - & - & 32 & 7 & - & - & - & - & - & - & 32 & 1.89 & 7 & $\mathrm{R}$ \\
\hline
\end{tabular}

Table. 1. Continued

These results are similar to those obtained by Omima Abdel-Monsef (2010). Anastasi et al., (2005) found that the total fungal load was up to $8.2 \times 10^{5} \mathrm{cfu} / \mathrm{g}$. Also, (Thambirajah et al., 1995). reported that the number of mesophilic fungi was $10^{6} \mathrm{cfu} / \mathrm{g}$ in mature compost.

The most common fungal genera and species were belonging to Aspergillus, Penicillium and Fusarium species. Aspergillus $\left(709 \times 10^{4}, 41.8 \%\right.$ of general total count \& 64 cases with high frequency of occurrence),
Penicillium $\left(282 \times 10^{4}, 16.63 \%\right.$ of general total count \& 40 cases out of 64 tested, with high frequency of occurrence), Fusarium (142 x $10^{4}, 8.37 \%$ of general total count \& 37 cases out of 64 tested with high frequency of occurrence)in addition to sterile mycelia (155 $\mathrm{x} 10^{4}, 9.14 \%$ of general total count $\& 33$ cases out of 64 tested with high frequency of occurrence)were the most prevalent genera isolated in composting process as stated in Table (1), Figs 1 (A \& B).

\begin{tabular}{|c|c|c|c|c|c|c|c|c|c|c|c|c|c|c|c|c|c|c|c|c|}
\hline \multirow{3}{*}{$\begin{array}{c}\text { Fungal genera and } \\
\text { species }\end{array}$} & \multicolumn{16}{|c|}{ Compost Treatments } & \multirow{3}{*}{$\begin{array}{c}\text { General } \\
\text { total } \\
\text { count }\end{array}$} & \multirow{3}{*}{$\%$} & \multirow{3}{*}{$\bar{Z}$} & \multirow{3}{*}{$\begin{array}{l}\mathrm{O} \\
\mathrm{R}\end{array}$} \\
\hline & \multicolumn{2}{|c|}{ TA } & \multicolumn{2}{|c|}{$\mathrm{TB}$} & \multicolumn{2}{|c|}{ TC } & \multicolumn{2}{|c|}{ TD } & \multicolumn{2}{|c|}{$\mathrm{TE}$} & \multicolumn{2}{|c|}{$\mathrm{TF}$} & \multicolumn{2}{|c|}{ TG } & \multicolumn{2}{|c|}{ TH } & & & & \\
\hline & U & $\bar{Z}$ & $U_{\ominus}$ & $\bar{Z}$ & 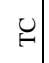 & $\bar{Z}$ & 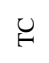 & $\ddot{Z}$ & U & $\bar{Z}$ & 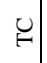 & $\bar{U}$ & U & Z゙ & U & $\bar{Z}$ & & & & \\
\hline $\begin{array}{c}\text { Scopulariopsis } \\
\text { brevicaulis }\end{array}$ & - & - & - & - & - & - & - & - & - & - & - & - & 13 & 3 & - & - & 13 & $\begin{array}{c}0.7 \\
7\end{array}$ & 3 & $\mathrm{R}$ \\
\hline $\begin{array}{c}\text { Fungal genera \& } \\
\text { species }\end{array}$ & \multicolumn{2}{|c|}{$\begin{array}{c}4 \& 7+ \\
\text { sterile } \\
\text { mycelia }\end{array}$} & \multicolumn{2}{|c|}{$\begin{array}{c}4 \& 7+ \\
\text { sterile } \\
\text { mycelia }\end{array}$} & \multicolumn{2}{|c|}{$\begin{array}{c}5 \& 8+ \\
\text { sterile } \\
\text { mycelia }\end{array}$} & \multicolumn{2}{|c|}{$\begin{array}{c}5 \& 9+ \\
\text { sterile } \\
\text { mycelia }\end{array}$} & \multicolumn{2}{|c|}{$5 \& 10$} & \multicolumn{2}{|c|}{$\begin{array}{c}4 \& 8+ \\
\text { sterile } \\
\text { mycelia }\end{array}$} & \multicolumn{2}{|c|}{$\begin{array}{c}4 \& 7+ \\
\text { sterile } \\
\text { mycelia }\end{array}$} & \multicolumn{2}{|c|}{$5 \& 8$} & & & & \\
\hline $\begin{array}{c}\text { Total fungal genera } \\
\text { \& species }\end{array}$ & \multicolumn{20}{|c|}{9 genera \& 19 species + sterile mycelia } \\
\hline
\end{tabular}

Table. 1. Continued 
TC: Total counts of fungi multiplied in $10^{4}$ NCI: Number of cases of isolation

OR: Occurrence remarks:-

(H) High: more than 32 out of 64 cases tested.

(M) Moderate: 16- 32 out of 64 cases tested

(L) Low: 8-15 out of 64 cases tested.

(R) Rare: less than 8 out of 64 cases tested

These results are in agreement with Van Heerden et al., (2002). This may be due to the composition of raw material (SBW) that is built up from cellulose, hemicellulose and lignin, which favor the growth of these fungi under mesophilic conditions. This finding is greatly supported by results of (Astaraei 2008). who suggested that the presence of fungi such as Aspergillus, Fusarium and Trichoderma in organic litters can be attributed to high contents of cellulose and hemicellulose in most of organic litters.

In this study, it was observed that A. niger was the most dominant species in all treatments inoculated with the same fungus. $A$. niger accounting $\left(240 \times 10^{4} \mathrm{cfu} / \mathrm{g}, 14.51 \%\right.$ of total count \& with high frequency of occurrence 55 cases out of 64 tested) and $A$. fumigatus matching $\left(155 \times 10^{4} \mathrm{cfu} / \mathrm{g}, 9.14 \%\right.$ \& with high frequency of occurrence 36 cases out of 64 tested) and $P$. chrysogenum recorded $\left(199 \times 10^{4} \mathrm{cfu} / \mathrm{g}, 11.73 \%\right.$ of total count $\&$ with high frequency of occurrence 33 cases out of 64 tested) were the most predominant species as stated in Table (1), Figs 1 (A \& B).

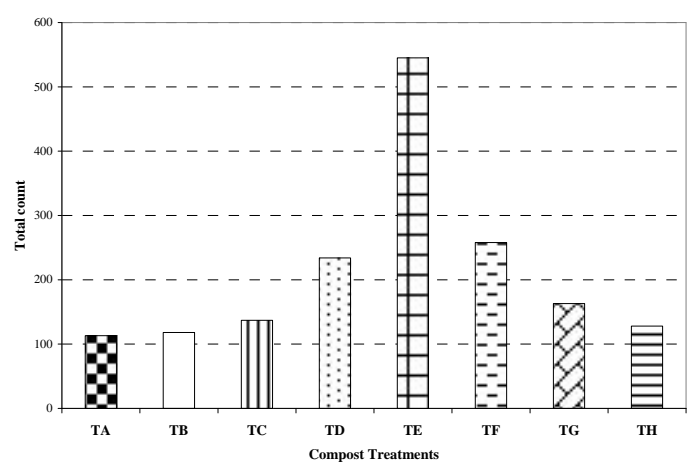

Fig. 1 (A). Comparison between total counts of mesophilic fungi of compost heaps isolated during different treatments of compostin process using dilution-plate method at $28^{\circ} \mathrm{C}$.

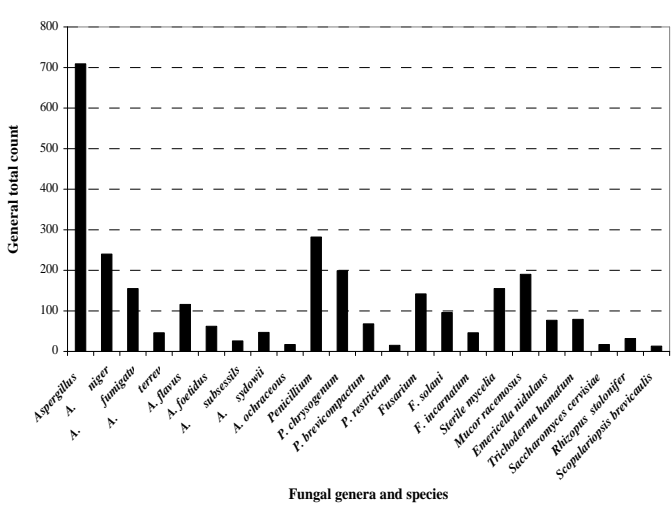

Fig. 1 (B). Comparison between different fungal genera and species of compost heaps isolated

during different treatments of composting process using dilution-plate method at $28^{\circ} \mathrm{C}$.

This flourish of A. niger may be due to the antagonistic activity that suppress the activity of other fungi in its own occurred area. This suggestion could be supported by SuarezEstrella (2007) and Omima Abdel-Monsef (2010).

Also, Rai and Upadhyay (2002) observed that colonization of pigeon-pea substrate by Fusarium udum was highly suppressed by antagonism from Penicillium citrinum, A. niger, Micromonospora globosa, A. flavus, A. terreus and Trichoderma viride when these fungi were used in inoculation. On the other hand, (Adegunloye et al., 2007). reported that A. niger was the predominant fungus isolated from compost specially at the latter weeks. (Gray and Briddlestone, 1981). suggested that the presence of $A$. niger could have been aided by its ability to adapt to the moderately high temperature of the compost $\left(25-30^{\circ} \mathrm{C}\right)$.

Also, Penicillium chrysogenum was prevalent, its frequencies and total counts were flourished on PDA, it was isolated also on the same medium from FYM during composting process under mesophilic conditions. It was isolated from mushroom compost and vermicompost by (Anastasi et al., 2002;Omima Abdel-Monsef,2010).reported that, $P$. chrysogenum was the most common species on PDA in composting process with TC, TD, TE, TF and TH. She suggested that $P$. chrysogenum was coming from air to these treatments and plays a role in the producing of antibiotics. This observation was in agreement 
with Suarez-Estrella (2007) who, confirmed that Penicillium spp. and other fungi have been identified as biocontrol agents in compost amended substrates and he also reported that most species of Penicillium produce antibiotic metabolites. Domsch et al. (1993) recorded that Penicillium spp. can degrade cellulose, lignin and pectin.

Also, in this study, Mucor racemosus (190 x $10^{4} \mathrm{cfu} / \mathrm{g}, 11.20 \%$ of total count \& 32 cases out of 64 tested), Fusarium solani ( $96 \times 10^{4}$ cfu/g, 5.66\% \& 29 cases), Aspergillus terreus (46 × $10^{4} \mathrm{cfu} / \mathrm{g}, 2.71 \%$ \& 25 cases), A. flavus $\left(116 \times 10^{4} \mathrm{cfu} / \mathrm{g}, \quad 6.84 \% \quad \& \quad 24\right.$ cases $)$, Emericella nidulans $\left(77 \times 10^{4} \mathrm{cfu} / \mathrm{g}, 4.54 \%\right.$ \& 23 cases) A. foetidus (62 x $10^{4} \mathrm{cfu} / \mathrm{g}, 3.66 \%$ \& 21 cases), A. subsessils ( $26 \times 10^{4} \mathrm{cfu} / \mathrm{g}, 1.53 \%$ $\& 21$ cases) and $F$. incarnatum (46 x $10^{4}$ $\mathrm{cfu} / \mathrm{g}, 2.71 \& 16$ cases) were isolated in moderate frequencies of occurrence. While, Trichoderma hamatum $\left(79 \times 10^{4} \mathrm{cfu} / \mathrm{g}, 4.66 \%\right.$ of total count \& 15 cases out of 64 tested), Penicillium brevicompactum $\left(68 \times 10^{4} \mathrm{cfu} / \mathrm{g}\right.$, $4.01 \%$ of total count \& 11 cases out of 64 tested) Aspergillus sydowii (47 x $10^{4} \mathrm{cfu} / \mathrm{g}$, $2.77 \%$ of total count \& 11 cases out of 64 tested), A. ochraceous (17 x $10^{4} \mathrm{cfu} / \mathrm{g}, 1.00 \%$ $\& 8$ cases)and Saccharomyces cervisiae $(17 \mathrm{x}$ $10^{4} \mathrm{cfu} / \mathrm{g}, 1.00 \%$ \& 8 cases) were isolated in low frequencies of occurrence. Whereas, Rhizopus stolonifer $\left(32 \times 10^{4} \mathrm{cfu} / \mathrm{g}, 1.89 \%\right.$ of total count \& 7 cases out of 64 tested), $P$. restrictum $\left(15 \times 10^{4} \mathrm{cfu} / \mathrm{g}, 0.89 \%\right.$ of total count \& 7 cases out of 64 tested) and Scopulariopsis brevicaulis $\left(13 \times 10^{4} \mathrm{cfu} / \mathrm{g}\right.$, $0.77 \%$ of total count \& 3 cases out of 64 tested) were isolated in rare frequencies of occurrence as stated in Table (1), Figs 1 (A \& B)..

Omima Abdel-Monsef (2010) reported that Scopulariopsis brevicaulis was isolated from date-palm residues and also isolated by Ryckeboer et al. (2003) from garden waste and municipal solid waste. The genus Scopulariopsis was mentioned by Tuomela $e t$ al. (2000) for its ability to degrade cellulose and lignin and also by Anastasi et al. (2002) to degrade keratin.

Results in this study are in harmony with the results recorded by Omima Abdel-Monsef (2010), who reported that in other treatments, other fungi e.g. Aspergillus sydowii, A. flavus, A. ochraceus, Rhizopus stolonifer, Penicillium brevicompactum, $P$. purpurogenum, Mucorracemosus, Stachybotrys chartarum, Fusarium incarnatum, Chaetomium globosum and Cladosporium cladosporioides were recorded in low counts.

Most of fungal genera isolated in this study during composting process like, Emericella, Rhizopus and Stachybotrys were reported as cellulose decomposers (Tuomela et al., 2000 and Rocha et al., 2002 and Omima AbdelMonsef 2010). Domsch et al. (1993) and Tuomela et al. (2000) recorded that Aspergillus spp. and Fusarium spp. can degrade cellulose, hemicellulose and lignin.

Cladosporium, Chaetomium and Mucor were isolated in this study during compost ripening in low frequenctes. The ability of these fungi to degrade cellulose, hemicellulose and lignin was proved by Domsch et al. (1993) and Tuomela et al. (2000).

According to mycological survey of different composted heaps, composted heaps of treatments C, D, E, F and G were preliminary selected for several physical and chemical tests in addition to pot experiment using wheat plant (Giza 168) as test plant to select the best organic compost can be applied in soil and plant fertilization.

\section{References:}

Abdel-Motaal, H.M. (2004). Production of organic fertilizer enriched with phosphorus from some agriculture wastes mixed with Rock phosphate. $\mathrm{Ph}$. D. Thesis. Fac. Agric. Minia University.

Adegunloye, D.V., Adetuyti, F.C, Akinyosoye, A. and Doyeni, M.O. (2007). Microbial analysis of compost using cow dung as booster. Pakistan J. of Nutrition. 6 (5): 506-510.

Ahmed, M.M.M., Mahmoud, A. M. and Osman, E.B.A. (2005). Recycling of crop residues and using them as a compost to enhance the growth and productivity of canola in newly reclaimed sandy soils. Res. Commun. of U.S.B. Branch Dobrich., 7: 138147. 
Anastasi, A., Giovanna, C.V. and Valeria, F.M. (2005). Isolation and identification of fungal communities in compost and vermicompost. Mycologia, 97(1): 33-44.

Anastasi, A., Varese, G.C., Voyron, S., Scannerini, S. and Marchisio, V.F. (2002). Systematic and functional characterization of fungal biodiversity in compost and vermicompost. In: Michel, F.C., Rynk, R.F. and Hoitink, H.A.J. (2002): Eds, Proceedings of the 2002 International Symposium "Composting and Compost Utilization". The JG Press Inc., Emmaus, pp. 171-182.

Ancuta, D., Renata, S. and Sumalen, R. (2011). Comparative study of aerobic microorganisms in compost. J. Horticulture, Forestry and Biotechnology, 15 (1), pp. 29-34.

Arvanitoyannis, I.S. and Tserkezou, P. (2008). Corn and rice waste: a comparative and critical presentation of methods and current and potential uses of treated waste. International Journal of Food and Technology, pp. 427- 431.

Astaraei, A.R. (2008). Microbial count and succession, soil chemical properties as affected by organic debrises decomposition. American-Eurasian J. Agric. \& Environ. Sci., 4(2): 178-188.

Booth, C. (1971). The genus Fusarium, Commonwealth Mycol. Institute, Kew, Surrey, England. pp. 327.

Booth, C. (1977). Fusarium laboratory guide to the identification of the major speies. Commonwealth Mycol. Institute, Kew, Surrey, England, pp. 58.

Brycekendrick, W., Conners, I.L. and Sigler, L. (1980). Genera of Hyphomycetes. The University of Alberta Press Edmonton. Alberta. Canada, pp. 386.

Christensen, M. and Raper,K.B. (1978). Synoptic key to Aspergillus nidulans group species and related Emericella species. Trans. Br. Mycol. Soc., 71(2): 177-191.

Diaz, L.F., Savage, G.M., Eggerth, L.L. and Golueke, C.G. (1993). Composting and Recycling Municipal Solid Waste. Leuis Pub., Bocaraton, Ann Arbor, London, Tokyo.

Domsch, K.H., Gams, W. and Anderson, T.H. (1993). Compendium of Soil Fungi, Vol.1, IHW-Verlag, Eching, Germany. El-Shafei, A., Yehia, M. and El-Naqib, F. (2008). Impact of effective microorganisms compost on soil fertility and rice productivity and quality. Misr J. Ag. En. Volume 25 (3): pp. 1067-1093.

El-Shenawi, M.R., Hoda Aly, S.H. and Badran, M.A.F. (2008). Response of Grandanian banana to humic acid potassium and magnesium fertilization. Alex. Sci. J. Vol. 29, No 4, pp. 252-255.

FAO (2013): http://www.fao.org. Recycling of organic wastes in agriculture.

Gabhane, J., William, S.P., Bidyadhar, R., Bhilawe, P., Anand, D., Vaidya, A.N. and Wate, S.R. (2012). Additives aided composting of green waste: Effects on organic matter degredation, compost maturity, and quality of the finished compost.Bioresource Technology, 114, pp. 382 -388.

Gaur, A.C. (1986). Recent trend in recycling of crop residues. Maharashtra Agric. Univ., 11:127-133.

Gaur, A.C. (1987). Recycling of organic wastes by improved techniques of composting and other methods. Resources and Conservation, Elsevier Sci. Pub. B.V., Amsterdam- Printed in the Netherlands, 13: pp. 157-174.

Gray, K.R. and Briddlestone, A.J. (1981). The composting of agricultural wsates. In: Stoneho. B. (ed) Biological Husbandry. Butter worths Publications. London, England. pp: 99-112.

Hammam, M.S. (2003). Effect of biofertilization on growth of fruiting of Cavendish and Williams banana, Egypt. J. Hort. 30 (1): pp. 67-82.

http://en.wikipedia. org/wiki/Grains

Johnson, L.F., Curl, E.A., Bond, J.H. and Fribourg, H.A. (1959). Methods for studying Soil microflora - plant 
disease relationships. Minne Polis. Publishing Co. U.S.A.; 178 pp.

Klich, M.A. and Pitt, J.I. (1992). A laboratory guide to the common Aspergillus species and their teleomorphs. Common Wealth Scientific and Industrial Research Organization, Division of Food Processing, North Ryde, Australia.

Kumar, A., Gaind, S. and Nain, L. (2008). Evaluation of thermophilic fungal consortium for paddy straw composition. Biodegradation, 19: pp. 395- 402.

Lawrence, Z. (1989).Aspergillus and Penicillium definition of the genera. C.A.B. Inter. Mycol. Inst., Kew, Surrey, England.

Leslie, J.F. and Summerell, B.A. (2006). The Fusarium laboratory manual. A Recent History. Mycotoxin Research, 22: pp.73-74.

Liu, J., Hong, X., Li, H. and Xu, X. (2011). Biomass and Bioenergy, Volume 35, pp. 3433-3439.

Martin, D.L. and Gershuny, G. (1992). The Rodale Book of Composting. Rodale Press, Emmaus, Pennsylvania.

Menzies, Y.J. (1957). A dipper technique for serial dilution of soil for microbial analyses. Proc. Soil. Sci. Soc. Am., 21: 660 .

Miller, E.W., Donahue, R.L. and Miller, J.U. (1990). Soil "an introduction to soils and plant growth" Brentice Hall International Inc. Engle Word Cliffs New Jersey, pp.210-220.

Mini, K., Udayasoorian, C. and Ramaswami, P.P. (1999). Bio conversion of paper and pulp mill solid wastes. Madras Agricultural Journal, 86: pp. 195-198.

Moubahser, A.H. (1993). Soil fungi in Qater and other Arab countries. Center for Scientific and Appl. Res. Univ. of Qater, Qater, pp. 566.

Nijjar, G.S. (1985). Nutrition of fruit trees. Mrs Usha Raj Kumar, Kalyani, New Delhi, pp.10-20.

Omima Abdel-Monsef. M. (2010). Composting of date palm wastes and effect on soil productivity and some soil properties. M.Sc. Thesis, Fac. Sci., Assiut Univ., Egypt.

Pitt, J.I. (1985). A laboratory guide to common Penicillium species. Commonwealth Scientific and Industrial Research Organization, Division of Food Research, North Ryde, N.S.W. Australia, Academic Press, INC. Ltd., London, pp. 184.

Rai, B. and Upadhyay, R.S. (2002). Competitive saprophytic colonization of pigeon-pea substrate by Fusariumudum in relation to environmental factors, chemical treatments and microbial antagonism. Soil Biol. Biochem. 15(2), pp. 187191.

Raper, K.B. and Fennell, D.I. (1965). The genus Aspergillus.Williams \& Wilkins, Baltimore, USA.

Raper, K.B. and Thom, C. (1949). A manual of Penicillium; Williams and Wilkins, Baltimore, USA. pp. 875.

Requena, N., Baca, T.M. and Azcon, R. (1997). Evolution of humic substances from unripe compost during inocubation with lignolytic or cellulolytic microorganisms and effects on the lettuce growth promotion mediated by Azotobacter chroococcum. Biol. Fertil. Soils, 24: pp. 59-65.

Rocha, M., Cordeiro, N., Cunha Queda, A.C. F. and Capela, R. (2002): Microbiological and chemical characterization during composting of cattle manure and forestry wastes-a study in Madeira Island. In: Michel, F. C., Rynk, R. F. and Hoitink, H. A. J. Eds, Proceedings of the 2002 International Symposium "Composting and Compost Utilization". The JG Press Inc., Emmaus, pp. 156-170.

Ryckeboer, J., Mergaert, J., Coosemans, J., Deprins, K. and Swings, J. (2003). Microbiological aspects of biowaste during composting in a monitored compost bin. J. Appl. Microbiol., 94(1): pp. 127-137. 
Suarez- Estrella, F., Vargas-Garcia, C., Lopez, M.J., Capel, C. and Moreno, J. (2007). Antagonistc activity of bacteria and fungi from horticultural compost against Fusarium oxysporum f. sp. melonis. Crop Protection 26: pp. 46-53.

SubbaRao, N.S. (1984). Biofertilizer in Agriculture Oxford and IBH Pub.New Delhi, India. pp. 137-181.

Tengerdy, R.P. and Szakacs, G. (2003). Bioconversion of lignocellulose in solid substrate fermentation. Biochem. Eng. J., 13: pp. 169-179.

Thambirajah, J.J., Zukali, M.D. and. Hashim, M.A. (1995). Microbiological and biochemical changes during composting of palm empty fruitbunches. Effect of nitrogen supplementation on the
substrate.Bioresource Technol. 52: pp. 133-144.

Tuomela, M., Vikman, M., Hatakka, A. and Itävaara, M. (2000): Biodegradation of lignin in a compost environment: A review. Bioresour. Technol., 72(2): pp. 169-183.

Turpeinen, B.K. (2007). Ligno-cellulose degradation and humus modification by the fungus Paecilomyces inflatus. Academic Dissertation of Microbiology, $9^{\text {th }}$ Ed. University of Helsinki, Finland.

Van Heerden, I., Cronje, C., Swart, S.H. and Kotze, J.M. (2002). Microbial, chemical and physical aspects of citrus waste composting. Bioresource Technol. 81: pp. 71-76.

Yang, L., Chen, Z., Liu, T., Li, B., Cao, X. and Yu, Y. (2013): Ecological indicators, volume 32, p. pp. 14-18.

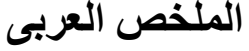

\section{فطريات التدوير الميكروبيولوجى لمخلفات الذرة الرفيعة إلى سماد عضوى فى مصر}

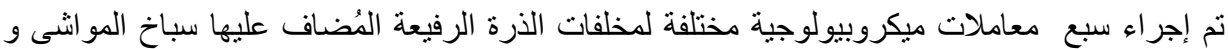

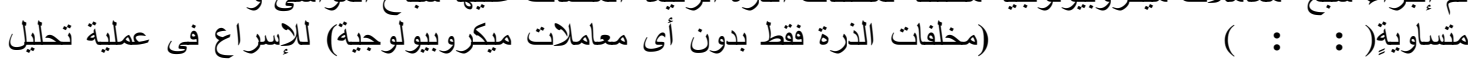

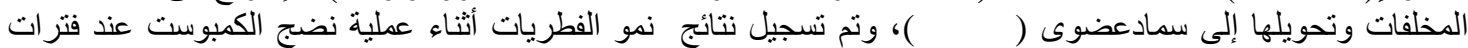

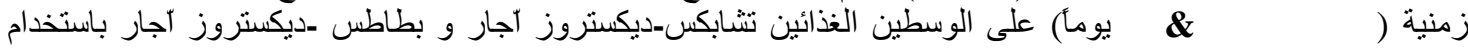

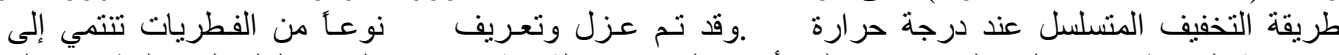

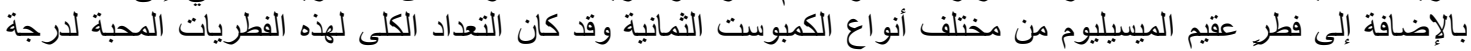

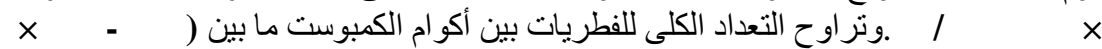

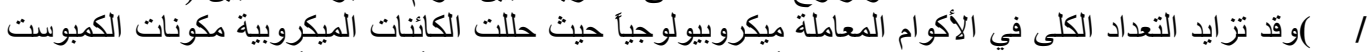

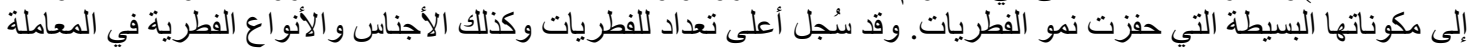

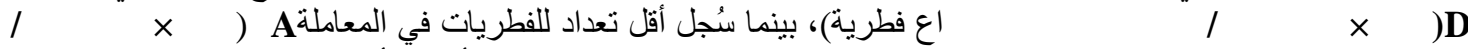

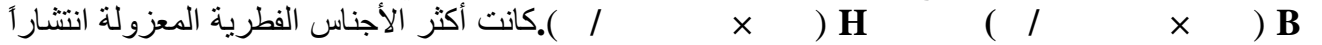

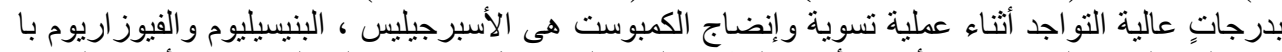

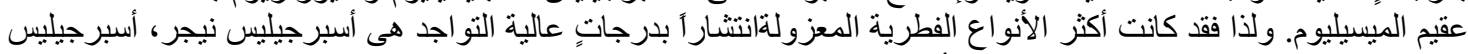

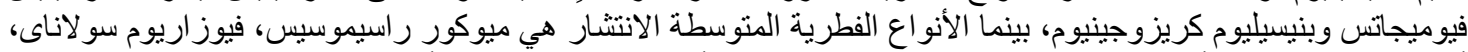

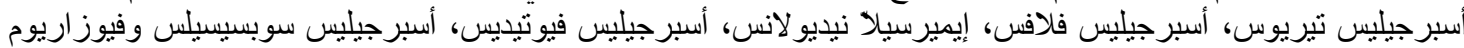

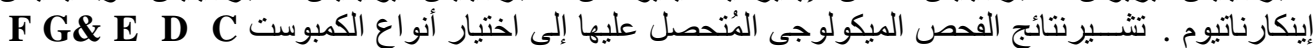

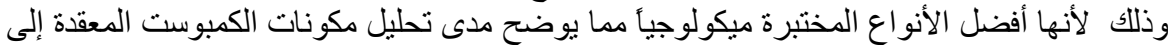
مكوناتها البسيطة التي يحتاجها النبات و التربة.
} 